\title{
Comparison of 4 Radiolabeled Antagonists for Serotonin 5-HT 7 Receptor Neuroimaging: Toward the First PET Radiotracer
}

\author{
Laetitia Lemoine $^{1,2}$, Julien Andries ${ }^{3}$, Didier Le Bars ${ }^{1,3,4}$, Thierry Billard ${ }^{1,3}$, and Luc Zimmer ${ }^{1,2,4}$ \\ ${ }^{I}$ CERMEP-Imagerie du Vivant, Lyon, France; ${ }^{2}$ University of Lyon 1, CNRS UMR5292, INSERM U1028, Lyon Neuroscience Research \\ Center, Lyon, France; ${ }^{3}$ University of Lyon 1, CNRS UMR5246, Institute of Chemistry and Biochemistry, Villeurbanne, France; and \\ ${ }^{4}$ Hospices Civils de Lyon, Lyon, France
}

Brain serotonin 7 (5-hydroxytryptamine 7 , or $5-\mathrm{HT}_{7}$ ) is the most recently identified serotonin receptor. It is involved in mood disorders and is studied as a target for antidepressants. Because no radioligand has yet been successfully used to study this receptor by PET neuroimaging, the objective of the present study was to develop a $5-\mathrm{HT}_{7}{ }^{18} \mathrm{~F}$-labeled radiotracer. Methods: Four structural analogs of SB269970, a specific 5$\mathrm{HT}_{7}$ receptor antagonist, were synthesized. The nitro precursors of these analogs were radiolabeled by ${ }^{18} \mathrm{~F}$ nucleophilic substitution. Analog antagonist effects were investigated by cellular functional assay. The cerebral distribution of radiolabeled molecules was studied by in vitro autoradiography in rats, and respective selectivity was determined by competition with the 5- $\mathrm{HT}_{7}$ receptor antagonist SB269970 at different concentrations. Ex vivo small-animal PET studies in rats and in vivo PET studies in cats focused on the 1-(2-\{(2R)-1-[(fluorophenyl)sulfonyl] pyrrolidin-2-yl\}ethyl)-4-methylpiperidine (FP3) series. Results: Four analogs were synthesized from the SB269970 pharmacophore and divided into an FP3 $\left({ }^{18} \mathrm{~F}-4 \mathrm{FP} 3\right.$ and $\left.{ }^{18} \mathrm{~F}-2 \mathrm{FP} 3\right)$ and an 1-(2-\{(2R)1-[(fluorophenyl)sulfonyl]pyrrolidin-2-yl\}ethyl)-4-(2-methoxyphenyl) piperazine (FPMP) $\left({ }^{18} \mathrm{~F}-2 \mathrm{FPMP}\right.$ and $\left.{ }^{18} \mathrm{~F}-4 \mathrm{FPMP}\right)$ series. The chemical and radiochemical purities of the 4 radiolabeled molecules were greater than $98 \%$. All presented suitable affinity for $5-\mathrm{HT}_{7}$ (apparent dissociation constant $\left[\mathrm{K}_{\mathrm{D}}\right]$ between 1.6 and $14 \mathrm{nM}$ ), although the FPMP series showed moderate agonist activity for $5-\mathrm{HT}_{1 \mathrm{~A}}$ receptors. Lipophilicity values were predictive of good radiotracer blood-brain barrier penetration (logD from 1.4 to 3.9). In vitro competition with a $5-\mathrm{HT}_{7}$ antagonist, SB269970, revealed that only radioligands from the FP3 series were displaced by the $5-\mathrm{HT}_{7}$-specific antagonist: subsequent in vivo study, therefore, focused on this series. Ex vivo ${ }^{18} \mathrm{~F}-4 \mathrm{FP} 3$ and ${ }^{18} \mathrm{~F}-$ $2 \mathrm{FP} 3$ autoradiography was in accordance with the $5-\mathrm{HT}_{7}$ brain distribution, with few brain radioactive metabolites. PET scans in cats showed that pretreatment with a $5-\mathrm{HT}_{7}$ antagonist significantly reduced ${ }^{18} \mathrm{~F}-2 \mathrm{FP} 3$ but not ${ }^{18} \mathrm{~F}-4 \mathrm{FP} 3$ binding. Conclusion: The 4 PET radiotracers had suitable characteristics for $5-\mathrm{HT}_{7}$ receptor probing in vitro, although the FP3 series seemed to be more specific for in vivo imaging of $5-\mathrm{HT}_{7}$ receptors. In particular, on the basis of the in vivo results, ${ }^{18} \mathrm{~F}-2 \mathrm{FP} 3$ appears to be

Received Feb. 14, 2011; revision accepted Jul. 19, 2011.

For correspondance or reprints contact: Luc Zimmer, CERMEP-Imagerie du Vivant, 59 Boulevard Pinel, F-69003 Lyon, France.

E-mail: zimmer@cermep.fr

Published online Oct. 11, 2011.

COPYRIGHT @ 2011 by the Society of Nuclear Medicine, Inc. the first PET radiotracer to enable in vivo imaging of $5-\mathrm{HT}_{7}$ receptors in animal models, possibly leading to neuroimaging studies in humans.

Key Words: PET; tracer development; $5-\mathrm{HT}_{7}$ receptors; rat; cat

J Nucl Med 2011; 52:1811-1818

DOI: 10.2967/jnumed.111.089185

O erotonin (5-hydroxytryptamine, or 5-HT) is a central neurotransmitter involved in many physiologic functions and in neurologic and psychiatric disorders. Pharmacologic studies identified numerous serotoninergic receptor families and subtypes, classified by structural, functional, and pharmacologic criteria into 7 distinct receptor classes $\left(5-\mathrm{HT}_{1-7}\right)(1)$.

The $5-\mathrm{HT}_{7}$ subtype is the most recently cloned serotonin receptor (2). $5-\mathrm{HT}_{7}$ receptors are coupled to $\mathrm{G}$ proteins (3) and are found in rodents, pigs, primates, and humans, with relatively high concentrations in the hippocampus, thalamus, and hypothalamus and lower levels in the cortex and amygdala (4-6). The 5- $\mathrm{HT}_{7}$ receptor exhibits a high degree of interspecies homology $(\sim 95 \%)$ but low sequence homology with other 5 -HT receptors $(<40 \%)(3,6)$. Three $5-\mathrm{HT}_{7}$ receptor isoforms, which differ only in their carboxyl terminal tails and have the same pharmacologic profile, are expressed in rats and humans (7).

The recent availability of selective $5-\mathrm{HT}_{7}$ receptor antagonists (7-9) and of 5- $\mathrm{HT}_{7}$ receptor knockout mice (10) has considerably advanced understanding of the physiologic function of this receptor (11). 5-HT 7 has been identified as important in circadian rhythms and sleep (12). It also binds several antidepressants (e.g., mianserin and maprotiline) and antipsychotics (e.g., clozapine and risperidone) with high affinity and may be a therapeutic target for schizophrenia and mood disorders. Selective 5- $\mathrm{HT}_{7}$ antagonists were indeed recommended in schizophrenia and depression (13-15). Several reports, based on receptor distribution and preliminary pharmacologic analyses, suggested $5-\mathrm{HT}_{7}$ receptors as a new serotoninergic target for memory enhancement, epilepsy, and pain (16-19). 
Therefore, serotonin $5-\mathrm{HT}_{7}$ receptor imaging in the human brain in vivo is needed to assess directly the involvement of the receptor in neuropsychiatric diseases and possible therapies. The development of PET as a molecular imaging method provides an opportunity for in vivo observation in both animal models and humans (20). This method requires a PET radiotracer that labels $5-\mathrm{HT}_{7}$ receptors with a high affinity and has a high selectivity, high signal-to-noise ratio, lipophilicity sufficient to penetrate the blood-brain barrier, relatively slow clearance, and low level of labeled metabolites in the brain (20).

Although several selective antagonists exist $(8,21,22)$, few have been radiolabeled for use in radioligand binding and autoradiography studies (23-26). For example, ${ }^{3} \mathrm{H}-\mathrm{SB} 269970$ is a high-affinity selective ligand (apparent dissociation constant $\left.\left[\mathrm{K}_{\mathrm{D}}\right], 1.2 \mathrm{nM}\right)(27)$ that has been used to radiolabel the $5-\mathrm{HT}_{7}$ receptor in vitro in rodent, pig, marmoset, and human brains $(5,28)$.

Notably, only 1 team developed a $5-\mathrm{HT}_{7}$ radiotracer for PET. DR4446 is a tetrahydrobenzindole derivative that possesses a higher selectivity for $5-\mathrm{HT}_{7}$ than the other $5-\mathrm{HT}$ receptors, although with only moderate affinity (apparent inhibition constant [Ki], $9.7 \mathrm{nM}$ ), and ${ }^{11} \mathrm{C}$-DR4446 was therefore synthesized and tested in monkeys (26). This preliminary PET study indicated that ${ }^{11} \mathrm{C}$-DR4446 had good cerebral uptake, had a specific binding component, and was metabolically stable. However, to our knowledge, no further reports have been published with this or other $5-\mathrm{HT}_{7} \mathrm{PET}$ radiotracers. We therefore sought to develop the first ${ }^{18} \mathrm{~F}$ labeled agonist PET probe to image functional $5-\mathrm{HT}_{7}$ receptors.

The present article describes the radiosynthesis of 4 original $5-\mathrm{HT}_{7}$ antagonists belonging to the 1-(2-\{(2R)-1-[(fluorophenyl) sulfonyl]pyrrolidin-2-yl\}ethyl)-4-methylpiperidine (FP3) and 1-(2-\{(2R)-1-[(fluorophenyl)sulfonyl]pyrrolidin-2-yl \}ethyl)4-(2-methoxyphenyl)piperazine (FPMP) series, with initial in vitro assessment. After favorable screening tests, the study focused on the 2FP3 series: ex vivo studies were performed in rats, and in vivo PET studies were performed in cats.

\section{MATERIALS AND METHODS}

\section{Precursor Synthesis}

We recently synthesized 4-methylpiperidine and 4-(2-methoxyphenyl) piperazine series as possible 5- $\mathrm{HT}_{7}$ PET radioligands (29). Briefly, (D)-proline was homologated in $N$-Boc-(D)-homoproline by a classic multistep homologation procedure, with an overall yield of $44 \%$. The $N$-Boc-(D)-homoproline was then coupled with the corresponding nitrogen heterocycle, depending on the expected series (4-methylpiperidine for the FP3 or 4-(2-methoxyphenyl) piperazine for the FPMP series), and the resulting amides were reduced in 2 steps. After removal of the Boc protection, the nitrophenylsulfonyl group (ortho- or para-nitro) was introduced, using the corresponding arylsulfonyl chloride, leading to the expected nitro precursors 1-(2-\{(2R)-1-[(nitrophenyl)sulfonyl]pyrrolidin-2-yl\}ethyl)4-methylpiperidine (NP3) or 1-(2-\{(2R)-1-[(nitrophenyl)sulfonyl] pyrrolidin-2-yl\}ethyl)-4-(2-methoxyphenyl)piperazine (NPMP) (Fig. 1).

\section{Tracer Radiolabeling and Quality Control}

${ }^{18} \mathrm{~F}$ was obtained by ${ }^{18} \mathrm{O}(p, n){ }^{18} \mathrm{~F}$ reaction (Cyclone $18 / 9$ cyclotron; IBA). Nitro-fluoro exchange was performed on a standard coincidence synthesizer (TracerLab Mx; GE Healthcare) after the automation sequence was reprogrammed. After initial fluoride preparation (collection, drying, and Kryptofix [Sigma-Aldrich] activation), $4 \mathrm{mg}$ of nitro precursor of 1 of the 4 molecules was introduced, and the reaction mixture was heated at $150^{\circ} \mathrm{C}$ for $10 \mathrm{~min}$ (29). After dilution with $15 \mathrm{~mL}$ of water, the reaction mixture was passed through an activated $\mathrm{C} 18$ cartridge for prepurification, and the crude product was eluted from the cartridge with $2 \mathrm{~mL}$ of ethanol. Pure fluorinated radiotracer was obtained after separation on a preparative high-performance liquid chromatography (HPLC) column (SymmetryPrep C18, $7 \mu \mathrm{m}, 7.8 \times 300 \mathrm{~mm}$; Waters) eluted with $20 \mathrm{mM} \mathrm{H}_{3} \mathrm{PO}_{4}$ /tetrahydrofuran/ $0.1 \%$ trifluoroacetic acid at $3 \mathrm{~mL} / \mathrm{min}$, with a retention time of $35 \mathrm{~min}$ for ${ }^{18} \mathrm{~F}$ 4FP3, $45 \mathrm{~min}$ for ${ }^{18} \mathrm{~F}-2 \mathrm{FP} 3,50 \mathrm{~min}$ for ${ }^{18} \mathrm{~F}-4 \mathrm{FPMP}$, and $70 \mathrm{~min}$ for ${ }^{18} \mathrm{~F}-2 \mathrm{FPMP}$. For in vivo use, the product was diluted with $40 \mathrm{~mL}$ of sterile water loaded onto a C18 cartridge (SEP-Pak Light; Waters), eluted with $1 \mathrm{~mL}$ of ethanol, diluted with isotonic saline to an ethanol concentration of $5 \%$, and sterilized by membrane filtration (Millex-GS, $0.22 \mu \mathrm{m}$; Millipore).

Quality control consisted of determining radiochemical purity and specific activity by analytic HPLC assay of an aliquot of the radiolabeled product, with comparison to the calibration curve generated from solutions of a known concentration (ultraviolet set at $254 \mathrm{~nm}$ and radioactive detection; C18 Nucleodur, $7.8 \times 300 \mathrm{~mm}$ column [Macherey-Nagel]; elution with $20 \mathrm{mM} \mathrm{H}_{3} \mathrm{PO}_{4} / 0.9 \mathrm{~mL}$ of tetrahydrofuran/minute for FP3 and $0.8 \mathrm{~mL} / \mathrm{min}$ for FPMP, with retention times of $9.5 \mathrm{~min}$ for ${ }^{18} \mathrm{~F}-4 \mathrm{FP} 3,7.6 \mathrm{~min}$ for ${ }^{18} \mathrm{~F}-2 \mathrm{FP} 3$, $8.8 \mathrm{~min}$ for ${ }^{18} \mathrm{~F}-4 \mathrm{FPMP}$, and $6.9 \mathrm{~min}$ for $\left.{ }^{18} \mathrm{~F}-2 \mathrm{FPMP}\right)$.

\section{Animals}

Adult male Sprague-Dawley rats (250-300 g of body weight; Charles River Laboratories) and European male cats (3.5-5 kg of body weight; Charles River Laboratories) were used. All animals were kept in the animal facility (room temperature, $22^{\circ} \mathrm{C}$, with a 12-h day-night cycle). All experiments were performed in accordance with European guidelines for care of laboratory animals (86/ 609 EEC) and were approved by the animal use ethics committee of the University of Lyon (University of Lyon 1).

\section{In Vitro Pharmacology}

Respective affinity toward $5-\mathrm{HT}_{7}$ receptors $\left(\mathrm{K}_{\mathrm{D}}\right)$ was determined by Cerep, an in vitro pharmacology company (30). Briefly, cellular functional assays were performed to search for possible antagonist and agonist effects in the 4 compounds. Competition binding experiments were performed on expressed human recombinant receptors in $\mathrm{CHO}$ cells. The $\mathrm{EC}_{50}$ value (concentration eliciting a half-maximal specific response) and $\mathrm{IC}_{50}$ value (concentration eliciting half-maximal inhibition of the control specific agonist response) were determined by nonlinear regression analysis of the concentration-response curves generated with mean replicate values using Hill equation curve fitting. Analysis used the commercial SigmaPlot 11.0 software (Systat Software Inc.). The $\mathrm{K}_{\mathrm{D}}$ was calculated using the modified Cheng Prusoff equation.

Lipophilicity $(\log$ P) was measured in our laboratory to evaluate the lipid solubility of radiolabeled molecules by partitioning between n-octanol and $50 \mathrm{mM}$ Tris- $\mathrm{HCl}$ (pH 7.4) buffer. Log $\mathrm{P}$ was calculated as the logarithm of the concentration of radiotracers in n-octanol over the concentration in buffer. 


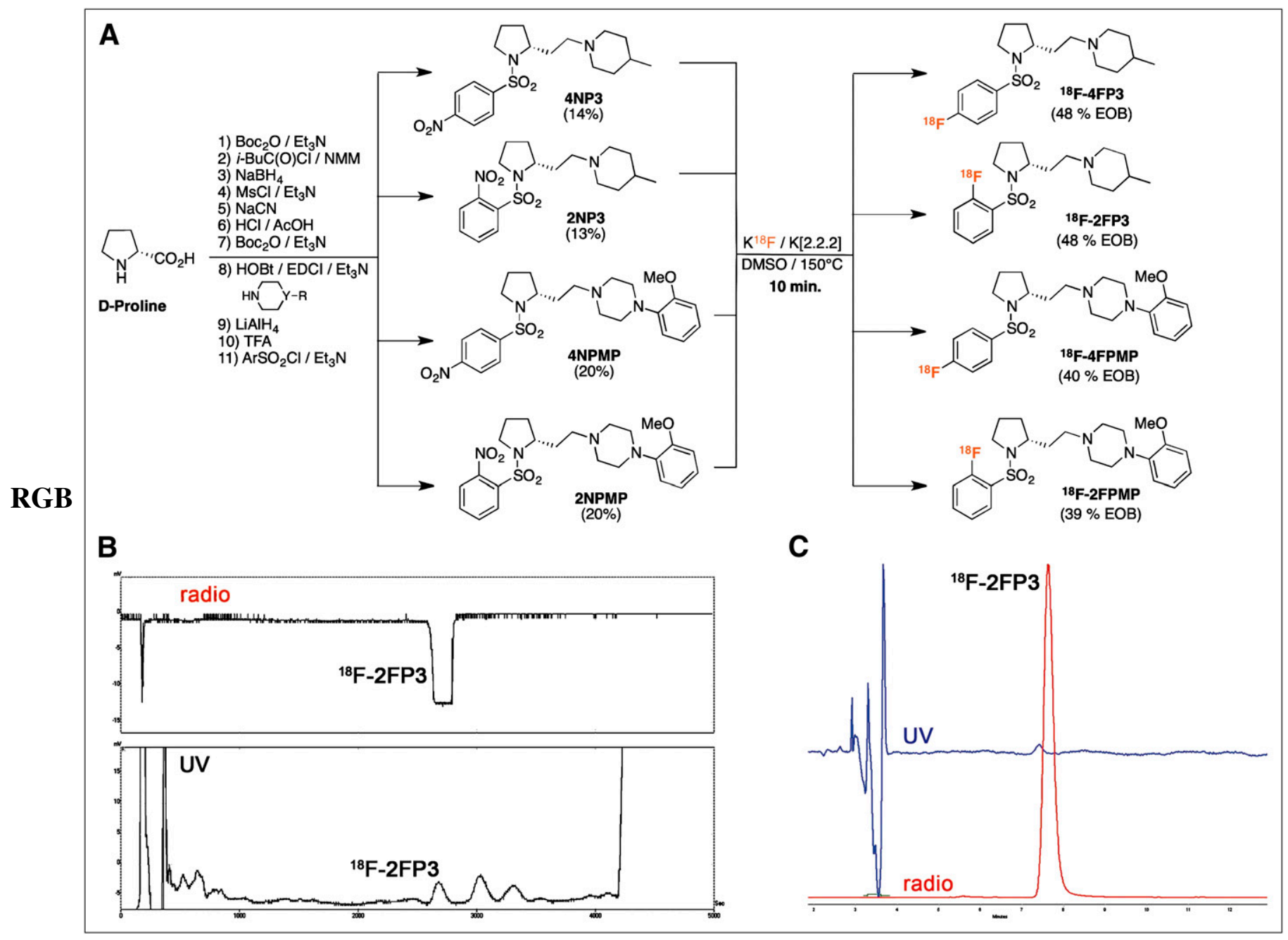

FIGURE 1. (A) Schema for synthesis of precursors 4NP3, 2NP3, 4NPMP, and 2NPMP, and radiosynthesis of ${ }^{18} \mathrm{~F}-4 \mathrm{FP} 3,{ }^{18} \mathrm{~F}-2 \mathrm{FP} 3,{ }^{18} \mathrm{~F}-$ 4FPMP, and ${ }^{18} \mathrm{~F}-2 \mathrm{FPMP}$. (B) Chromatogram of HPLC purification of ${ }^{18} \mathrm{~F}-2 \mathrm{FP} 3$ (ultraviolet absorbance at $254 \mathrm{~nm}$ and radioactivity). (C) Quality control chromatogram of final ${ }^{18} \mathrm{~F}-2 \mathrm{FP} 3$ (ultraviolet absorbance at $254 \mathrm{~nm}$ and radioactivity) shows radiochemical purity greater than $99 \%$. DMSO = dimethyl sulfoxide; $\mathrm{EOB}=$ end of bombardment; radio = radioactivity detection; UV = ultraviolet detection.

\section{In Vitro Studies of ${ }^{18}$ F-FPMP and ${ }^{18}$ F-FP3 Series}

In vitro autoradiography was performed in rats. After euthanasia by inhaled isoflurane overdose, rat brains were carefully removed and immediately frozen in 2-methylbutane cooled with dry ice $\left(-29^{\circ} \mathrm{C}\right)$. Briefly, coronal sections $(30 \mu \mathrm{m}$ thick) across the hippocampus and cerebellum were cut using a $-20^{\circ} \mathrm{C}$ cryostat (SM1850; Leica), thaw-mounted on glass slides, and allowed to air-dry before storage at $-80^{\circ} \mathrm{C}$ until use. On the day of radiotracer synthesis, the slides were allowed to reach room temperature and then incubated for $20 \mathrm{~min}$ in Tris phosphate-buffered saline $(138 \mathrm{mM}$ $\mathrm{NaCl}, 2.7 \mathrm{mM} \mathrm{KCl}, \mathrm{pH}$ adjusted to 7.6$)$ containing $37 \mathrm{kBq} / \mathrm{mL}$ $(1 \mu \mathrm{Ci} / \mathrm{mL})$ of ${ }^{18} \mathrm{~F}-4 \mathrm{FP} 3,{ }^{18} \mathrm{~F}-2 \mathrm{FP} 3,{ }^{18} \mathrm{~F}-4 \mathrm{FPMP}$, or ${ }^{18} \mathrm{~F}-2 \mathrm{FPMP}$. For competition experiments, the slides were placed in the same buffer supplemented with SB269970, a selective 5- $\mathrm{HT}_{7}$ antagonist $(10 \mathrm{nM}, 100 \mathrm{nM}$, or $1 \mu \mathrm{M})$, or with serotonin $(1 \mu \mathrm{M})$. After incubation, slides were dipped in cold buffer $\left(4^{\circ} \mathrm{C}\right)$ for $90 \mathrm{~s}$ and in distilled cold water $\left(4^{\circ} \mathrm{C}\right)$ for $90 \mathrm{~s}$, and then dried and juxtaposed to a phosphor imaging plate for $60 \mathrm{~min}$ (BAS-1800 II; Fujifilm). Regions of interest (cingulate cortex and hippocampus) were drawn manually using Multigauge software (Fujifilm). Results were expressed in phosphostimulated luminescence per millimeter squared and converted into percentage of control.

\section{Ex Vivo Studies of ${ }^{18}$ F-FP3 Series}

The ex vivo and in vivo small-animal PET images were acquired on a ClearPET LYSO/LuYAP Phoswich scanner (Raytest) in 3-dimensional mode (31). In the first part of the experiment, rats were anesthetized with urethane (1.25 g/ $\mathrm{kg}$ intraperitoneally), and an intravenous catheter was inserted in the caudal vein. ${ }^{18} \mathrm{~F}-4 \mathrm{FP} 3$ or ${ }^{18} \mathrm{~F}-2 \mathrm{FP} 3$ (55.5 MBq intravenously) was injected, and $20 \mathrm{~min}$ after radiotracer injection, the anesthetized rat was killed by decapitation. The brain was carefully and rapidly removed and centered in the field of view of the small-animal PET camera. Radioactivity was measured in a single 45-min frame. In the second part of the experiment, rats were similarly anesthetized and catheterized. SB269970, the selective $5-\mathrm{HT}_{7}$ antagonist, was administered $(5 \mathrm{mg} / \mathrm{kg}$ intravenously) $30 \mathrm{~min}$ before injection of ${ }^{18} \mathrm{~F}-4 \mathrm{FP} 3$ or ${ }^{18} \mathrm{~F}-2 \mathrm{FP} 3(55.5 \mathrm{MBq}$ intravenously). In another experiment, the corresponding cold fluorinated radiotracer was administered ( $5 \mathrm{mg} / \mathrm{kg}$ intravenously) $30 \mathrm{~min}$ before injection of ${ }^{18} \mathrm{~F}-4 \mathrm{FP} 3$ or ${ }^{18} \mathrm{~F}-2 \mathrm{FP} 3$ (55.5 MBq intravenously). 
Twenty minutes after radiotracer injection, the brain was carefully removed and placed in the small-animal PET camera for a 45-min acquisition. The images obtained were analyzed with AMIDE software (A Medical Imaging Data Examiner; free license).

\section{In Vivo Studies of ${ }^{18} \mathrm{~F}-2 \mathrm{FP} 3$}

Cat PET Scan Acquisition. PET scans were acquired for European male cats anesthetized with isoflurane (Baxter) administered at $5 \%$ for $5 \mathrm{~min}$ and then lowered to $2.5 \%$. The cat was placed in an acrylic stereotactic apparatus with ear bars, and a catheter was inserted into the forearm branch of the brachiocephalic vein, continuously perfused with $\mathrm{NaCl} 0.9 \%$. PET scans were acquired on an Exact ECAT HR+ (CTI-Siemens) in 3dimensional mode. The first $10 \mathrm{~min}$ of acquisition was the transmission scan, performed with 3 rotating ${ }^{68} \mathrm{Ge}$ and ${ }^{68} \mathrm{Ga}$ sources, followed by a 74-MBq (2-mCi) injection of ${ }^{18} \mathrm{~F}-2 \mathrm{FP} 3$. Radioactivity was measured in a series of 31 sequential frames of increasing duration from $30 \mathrm{~s}$ to $10 \mathrm{~min}$; total scan time was $90 \mathrm{~min}$. Images were reconstructed in the frontal plane. Regions of interest (cingulate cortex, thalamus, hippocampus, and cerebellum) were manually drawn using CAPP software (CTI-Siemens) according to the stereotactic atlas of the cat brain $(32,33)$ and the MR images. The radioactivity of different regions attributed to the fixation of ${ }^{18} \mathrm{~F}-2 \mathrm{FP} 3$ was expressed in becquerels per centimeter cubed.

Cat MR Image Acquisition. The same cats were anesthetized with isoflurane administered at $5 \%$ for $5 \mathrm{~min}$ and then lowered to $2.5 \%$. The head of the animal was immobilized in a stereotactic acrylic frame with ear bars and orbital and hard palate parts. MR image acquisition (1.5-T Magnetom scanner; Siemens AG) comprised a 40-min 3-dimensinal anatomic T1-weighted sequence. The anatomic volume covered the whole brain with $0.7 \mathrm{~mm}^{3}$ voxels.

\section{Determination of Unchanged ${ }^{18} \mathrm{~F}-2 \mathrm{FP} 3$ in Rat Brain}

Three series of 2 rats were anesthetized by intraperitoneal injection of urethane $(1.7 \mathrm{~g} / \mathrm{kg})$, and a catheter was inserted into the caudal vein. The rats were killed by decapitation at $10,20,30$, and $40 \mathrm{~min}$ after a bolus injection of ${ }^{18} \mathrm{~F}-2 \mathrm{FP} 3(55.5$ $\mathrm{MBq}[1.5 \mathrm{mCi}])$. The brains were rapidly removed; the cerebral hemisphere was homogenized by an ultrasonic homogenizer in $400 \mu \mathrm{L}$ of perchloric acid $(0.4 \mathrm{~mol} / \mathrm{L})$, and the mixture was neutralized by $120 \mu \mathrm{L}$ of $4 \mathrm{M}$ potassium acetate. After centrifugation at $5,000 \mathrm{~g}$ for $10 \mathrm{~min}$, the supernatant was filtered $(0.45 \mu \mathrm{m})$ before HPLC. The HPLC system consisted of a C-18 reversed-phase column (Nucleodur, $7.8 \times 300 \mathrm{~mm}$; Macherey-Nagel) (elution with H3PO4 [20 nM]/tetrahydrofuran: $85 / 15$ at a flow rate of $0.9 \mathrm{~mL} / \mathrm{min}$ ). During elution, 2-min fractions were collected and counted for radioactivity with an automated $\gamma$-counter (Cobra II; Packard).

\section{RESULTS}

Nitro Precursor Synthesis and ${ }^{18} \mathrm{~F}-4 \mathrm{FP} 3,{ }^{18} \mathrm{~F}-2 \mathrm{FP} 3$, ${ }^{18} \mathrm{~F}-4 \mathrm{FPMP}$, or ${ }^{18} \mathrm{~F}-2 \mathrm{FPMP}$ Radiosynthesis

The synthetic routes for the preparation of the FP3 and FPMP series and their radiolabeling are summarized in Figure 1A. Precursors were synthesized in 9 steps from (D)-proline, with an overall yield in the range of 13\%-20\%.

The radiolabeling of the 4 radiotracers was obtained from their nitro precursors at $150^{\circ} \mathrm{C}$, with a radiochemical yield between $39 \%$ and $48 \%$ corrected for decay and 100-120 min radiosynthesis time (including HPLC purification and formulation), using a reprogrammed automated fluorination module. No radioactive by-products were observed (Fig. 1B), and the selected HPLC conditions ensured good separation of ${ }^{18} \mathrm{~F}-4 \mathrm{FP} 3,{ }^{18} \mathrm{~F}-2 \mathrm{FP} 3,{ }^{18} \mathrm{~F}-4 \mathrm{FPMP}$, or ${ }^{18} \mathrm{~F}-2 \mathrm{FPMP}$ from their respective nitro precursors, as confirmed on quality control (Fig. 1C). Radiochemical purity was better than $98 \%$, and the specific activity of the 4 molecules was between 40 and 130 $\mathrm{GBq} / \mu \mathrm{mol}$, corrected at the end of synthesis.

\section{Partition Coefficient Measurement}

The lipophilicity of the fluorinated molecules, determined in vitro by the octanol-water partition coefficient $(\log \mathrm{P})$, was found to be between 1.2 and 1.4 for the FP3 series and between 3.4 and 3.9 for the FPMP series (average of 3 experiments). These values were confirmed with the calculated $\log \mathrm{D}$ (ACD/ChemSketch software, version 7.0; ACD/Labs).

\section{In Vitro Pharmacology}

The measured $\mathrm{K}_{\mathrm{D}}$ demonstrated good affinity of the fluorinated molecules for the $5-\mathrm{HT}_{7}$ receptor, in particular for the FPMP series, with a value below $2 \mathrm{nM}$ and antagonist properties $\left({ }^{18} \mathrm{~F}-4 \mathrm{FP} 3 \mathrm{~K}_{\mathrm{B}}, 1.92 ;{ }^{18} \mathrm{~F}-2 \mathrm{FP} 3 \mathrm{~K}_{\mathrm{B}}, 1.43 ;{ }^{18} \mathrm{~F}-4 \mathrm{FPMP}\right.$ $\mathrm{K}_{\mathrm{B}}, 3.89$; and ${ }^{18} \mathrm{~F}-2 \mathrm{FPMP} \mathrm{K}_{\mathrm{B}}, 3.38$ ). In terms of $5-\mathrm{HT}_{1 \mathrm{~A}}$ affinity, the FPMP series showed a $5-\mathrm{HT}_{1 \mathrm{~A}}$ agonist contribution $\left(\mathrm{EC}_{50}, 1.4 \times 10^{-7}\right.$ for ${ }^{18} \mathrm{~F}-4 \mathrm{FPMP}$ and $5.8 \times 10^{-8}$ for ${ }^{18} \mathrm{~F}-$ 2FPMP), unlike the FP3 series, which was without $5-\mathrm{HT}_{1 \mathrm{~A}}$ contribution $\left(\mathrm{EC}_{50}>>10^{-5}\right)$. No radiotracers showed 5- $\mathrm{HT}_{6}$ affinity $\left(\mathrm{EC}_{50}>>10^{-5}\right)$.

\section{In Vitro Distribution Studies}

The distributions of ${ }^{18} \mathrm{~F}-4 \mathrm{FP} 3,{ }^{18} \mathrm{~F}-2 \mathrm{FP} 3,{ }^{18} \mathrm{~F}-4 \mathrm{FPMP}$, and ${ }^{18} \mathrm{~F}$-2FPMP were assessed by semiquantitative autoradiography in rat brains (Fig. 2A). Autoradiograms obtained after incubation with a constant in vitro radiotracer concentration demonstrated the presence of structures able to concentrate radioactivity - that is, cortex, hippocampus, thalamus, and cerebellum. These binding areas corresponded to those described as rich in $5-\mathrm{HT}_{7}$ receptors (6). The binding level in the FPMP series ( ${ }^{18} \mathrm{~F}$-4FPMP and ${ }^{18} \mathrm{~F}$-2FPMP) was higher in the hippocampus than in other regions, whereas the level of hippocampus binding in the FP3 series $\left({ }^{18} \mathrm{~F}-\right.$ 4FP3 and ${ }^{18} \mathrm{~F}-2 \mathrm{FP} 3$ ) was similar to that in other regions (experiments performed in triplicate for each radiotracer).

\section{In Vitro Competition Studies}

${ }^{18} \mathrm{~F}-4 \mathrm{FP} 3$ and ${ }^{18} \mathrm{~F}-2 \mathrm{FP} 3$ radioactivity measured in displacement experiments in the hippocampus and cingulate cortex was reduced markedly and dose-dependently after the addition of SB269970, a 5- $\mathrm{HT}_{7}$ receptor antagonist (performed in triplicate). Diminution in ${ }^{18} \mathrm{~F}-4 \mathrm{FP} 3$ binding in cingulate cortex was $-40 \%$ and $-70 \%$ with $100 \mathrm{nM}$ and $1 \mu \mathrm{M}$ SB269970, respectively, and in the hippocampus $-20 \%$, $-40 \%$, and $-60 \%$ with $10 \mathrm{nM}, 100 \mathrm{nM}$, and $1 \mu \mathrm{M}$, respectively. Diminution in ${ }^{18} \mathrm{~F}-2 \mathrm{FP} 3$ binding in the hippocampus was $-40 \%,-60 \%$, and $-70 \%$ with $10 \mathrm{nM}$, $100 \mathrm{nM}$, and $1 \mu \mathrm{M} \mathrm{SB} 269970$, respectively, and in the cingulate cortex $-40 \%,-60 \%$, and $-70 \%$ with $10 \mathrm{nM}$, 


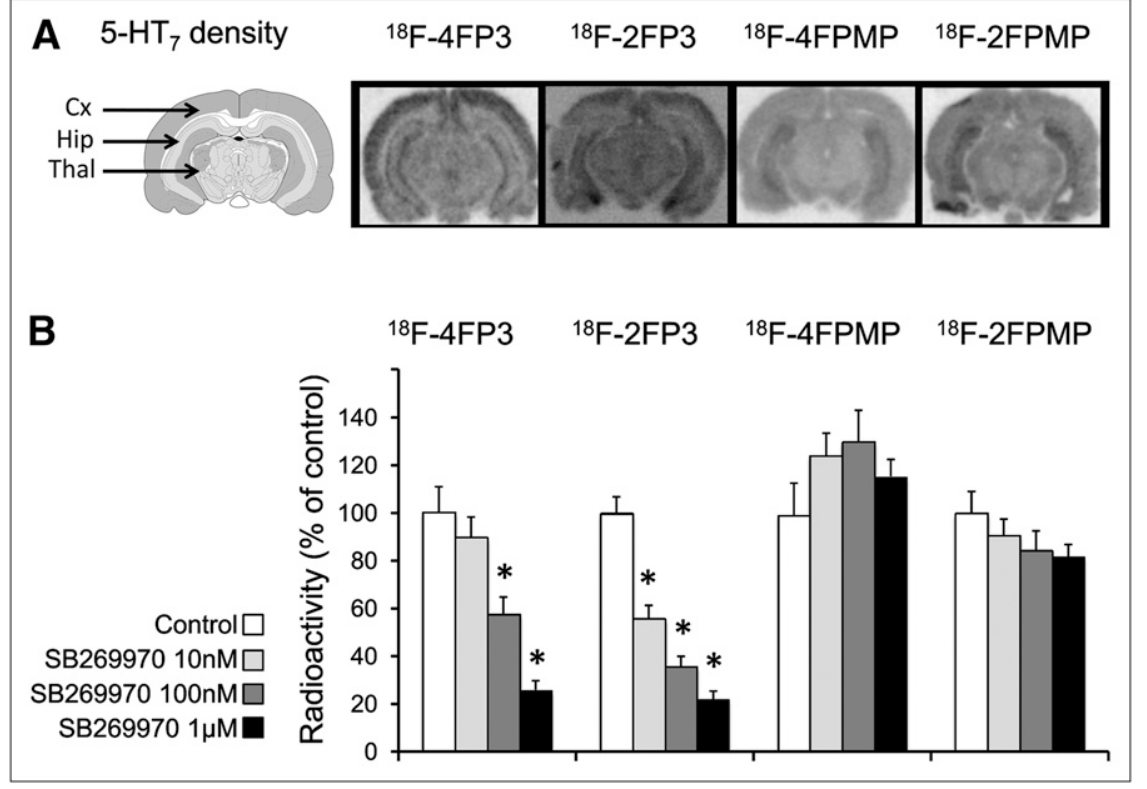

FIGURE 2. (A) In vitro autoradiograms of rat brain sections incubated with ${ }^{18} \mathrm{~F}-4 \mathrm{FP} 3$, ${ }^{18} \mathrm{~F}-2 \mathrm{FP} 3,{ }^{18} \mathrm{~F}-4 \mathrm{FPMP}$, or ${ }^{18} \mathrm{~F}-2 \mathrm{FPMP}$ show locations and density of $5-\mathrm{HT}_{7}$ receptors (proportional to gray level) in hippocampus (Hip), cortex (Cx), and thalamus (Thal). (B) Histograms obtained by in vitro autoradiography in rats and competition between ${ }^{18} \mathrm{~F}$ 4FP3, ${ }^{18} \mathrm{~F}-2 \mathrm{FP} 3,{ }^{18} \mathrm{~F}-4 \mathrm{FPMP},{ }^{18} \mathrm{~F}-2 \mathrm{FPMP}$, and SB269970, a 5- $\mathrm{HT}_{7}$ receptor antagonist. Radioactivity in cortex is represented at different concentrations and expressed as percentage of control. Mean values ( \pm SEM) for each group are significantly different $\left({ }^{\star} P<0.05\right)$ from controls on unpaired Student $t$ test. DMSO = dimethyl sulfoxide; $\mathrm{EOB}=$ end of bombardment; radio = radioactivity detection; UV = ultraviolet detection.
$100 \mathrm{nM}$, and $1 \mu \mathrm{M}$, respectively (Fig. 2B). At the same concentrations of SB269970 and in the same brain areas, ${ }^{18} \mathrm{~F}$-4FPMP and ${ }^{18} \mathrm{~F}-2 \mathrm{FPMP}$ binding remained unchanged (Fig. 2B).

In other experiments, incubation with $1 \mu \mathrm{M}$ serotonin reduced ${ }^{18} \mathrm{~F}-2 \mathrm{FP} 3$ binding by $40 \%$ in the cingulate cortex and hippocampus but failed to modify ${ }^{18} \mathrm{~F}-4 \mathrm{FP} 3,{ }^{18} \mathrm{~F}-4 \mathrm{FPMP}$, or ${ }^{18} \mathrm{~F}-2 \mathrm{FPMP}$ binding (performed in triplicate, results not shown).

\section{Ex Vivo ${ }^{18} \mathrm{~F}-4 \mathrm{FP} 3$ and ${ }^{18} \mathrm{~F}-2 \mathrm{FP} 3$ Binding in Rat Brain}

The small-animal PET images obtained in isolated rat brain showed ${ }^{18} \mathrm{~F}-4 \mathrm{FP} 3$ and ${ }^{18} \mathrm{~F}-2 \mathrm{FP} 3$ binding in a $5-\mathrm{HT}_{7}-$ rich region (cortex and cerebellum). Preinjection of unlabeled 4FP3 or $2 \mathrm{FP} 3$ significantly decreased ${ }^{18} \mathrm{~F}-4 \mathrm{FP} 3$ and ${ }^{18} \mathrm{~F}-2 \mathrm{FP} 3$ binding in all brain areas (experiments performed in duplicate, Fig. 3). Preinjection of SB269970 (5 mg/kg) decreased ${ }^{18} \mathrm{~F}-4 \mathrm{FP} 3$ and ${ }^{18} \mathrm{~F}-2 \mathrm{FP} 3$ binding in all brain areas (experiments performed in duplicate, Fig. 3).

\section{In Vivo ${ }^{18} \mathrm{~F}-4 \mathrm{FP3}$ and ${ }^{18} \mathrm{~F}-2 \mathrm{FP} 3$ Binding in Cat Brain}

In vivo $\mathrm{PET}$ images in cats revealed that after intravenous injection of ${ }^{18} \mathrm{~F}-4 \mathrm{FP} 3$ and ${ }^{18} \mathrm{~F}-2 \mathrm{FP} 3$, there was rapid accumulation of the radioligand (Fig. 4). Time-activity curves showed high initial uptake in the hippocampus, cingulate cortex, thalamus, and cerebellum. Binding ratios were obtained with time curves integrated from 5 to $45 \mathrm{~min}$.

After SB269970 preinjection, ${ }^{18} \mathrm{~F}-2 \mathrm{FP} 3$ concentrations fell to near zero in all regions, whereas ${ }^{18} \mathrm{~F}-4 \mathrm{FP} 3$ binding remained unchanged (experiments performed in duplicate for each radiotracer)

\section{Unmetabolized ${ }^{18}$ F-2FP3 in Rat Brain}

In rat brain, over the time scale considered $(10,20,30$, and $40 \mathrm{~min}$ after injection), the only radioactive peak detected after HPLC separation was due to the parent compound, unchanged ${ }^{18} \mathrm{~F}-2 \mathrm{FP} 3$ (95\% for each time point; experiments performed in duplicate).

\section{DISCUSSION}

The aim of the study was to select and evaluate a potential PET radioligand for in vivo imaging of brain $5-\mathrm{HT}_{7}$ receptors. The strategy was to synthesize 4 molecules and their nitro precursors and to focus in vivo study on the best molecules in terms of specificity and in vitro properties.

From a chemical standpoint, the choice of FP3 and FPMP series structures was inspired by a pharmacophore model (34) and by the structure of SB269970, the prototypical $5-\mathrm{HT}_{7}$ antagonist $(27,35)$. The ortho and para positions were chosen for fluorine nucleophilic substitution, and

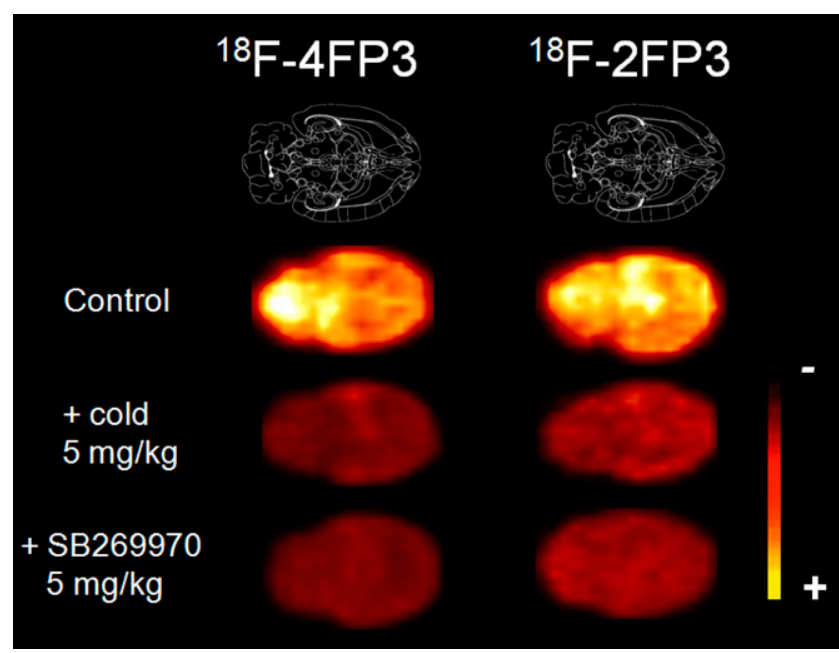

\section{RGB}

FIGURE 3. Ex vivo coronal small-animal PET images of ${ }^{18} \mathrm{~F}-4 \mathrm{FP} 3$ or ${ }^{18} \mathrm{~F}-2 \mathrm{FP} 3$ binding in isolated rat brain (45-min acquisition), $20 \mathrm{~min}$ after radioligand injection. 


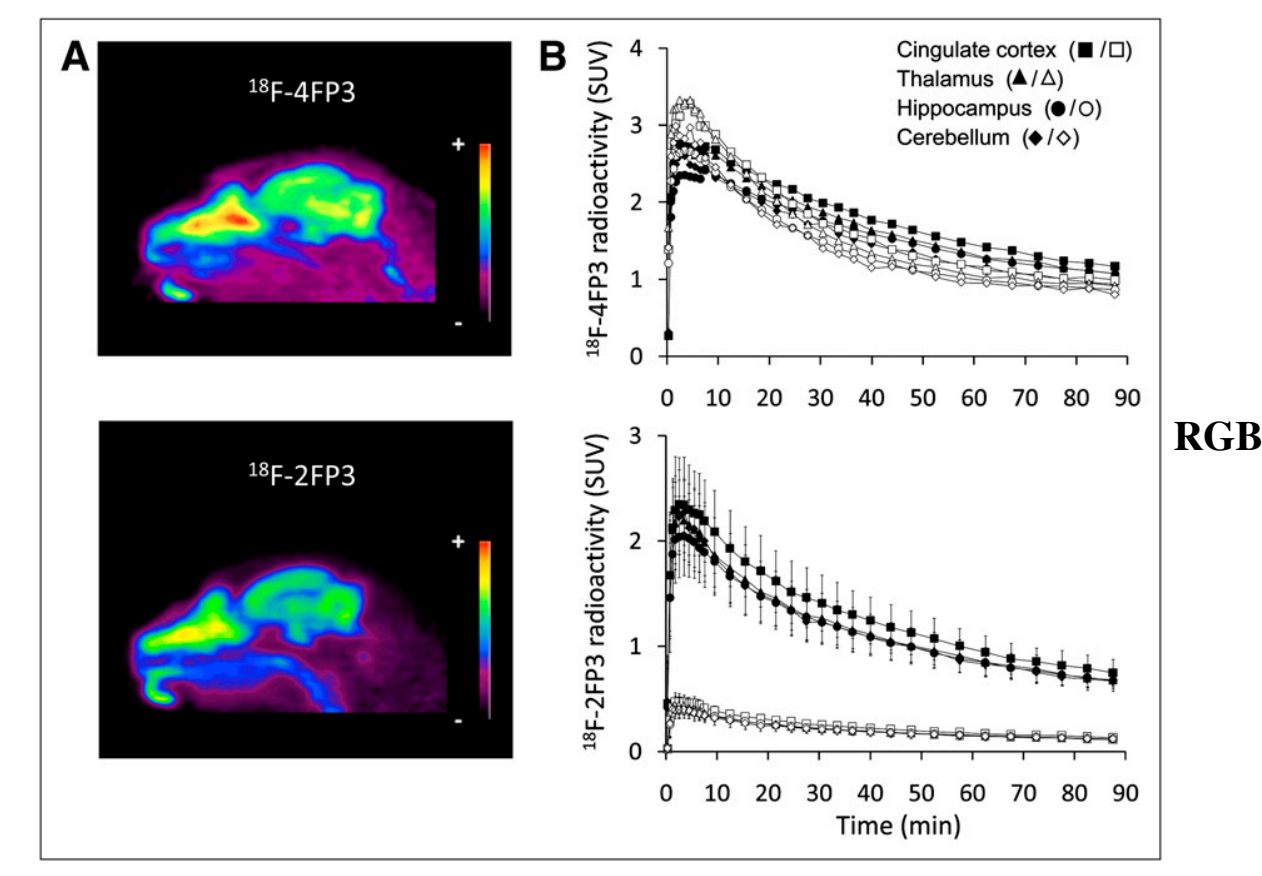

FIGURE 4. (A) Representative sagittal PET images summed for 0-90 scans, showing ${ }^{18} \mathrm{~F}-4 \mathrm{FP} 3$ and ${ }^{18} \mathrm{~F}-2 \mathrm{FP} 3$ distribution in cat brain. (B) Time-activity curves of ${ }^{18} \mathrm{~F}-4 \mathrm{FP} 3$ and ${ }^{18} \mathrm{~F}-2 \mathrm{FP} 3$ PET tracers at baseline (closed symbols) and after blockade with intravenous SB269970 (open symbols), a $5-\mathrm{HT}_{7}$ antagonist $(5 \mathrm{mg} / \mathrm{kg}, 30 \mathrm{~min}$ before radiotracer injection) (duplicated experiments).

2 hydrophobic groups were selected, leading to the synthesis of the FP3 series (4FP3 with ${ }^{18} \mathrm{~F}$ in para, and $2 \mathrm{FP} 3$ with ${ }^{18} \mathrm{~F}$ in ortho) and FPMP series (4FPMP with ${ }^{18} \mathrm{~F}$ in para, and 2FPMP with ${ }^{18} \mathrm{~F}$ in ortho). The labeling of the nitro precursor of the 4 tracer candidates was straightforward, with excellent radiochemical purity and a satisfactory specific activity.

2FP3 series lipophilicity measured in vitro was compatible with blood-brain barrier uptake. On the other hand, the relatively high lipophilicity of the FPMP series exposed it to higher nonspecific binding after radiolabeling, although this parameter is not systematically predictive for radiotracers (36). In vitro assay revealed the nanomolar affinity of the 4 molecules for the $5-\mathrm{HT}_{7}$ receptor, as previously reported for SB269970, the prototypical 5- $\mathrm{HT}_{7}$ antagonist (28). Such affinities (in the range of $1-10 \mathrm{nM}$ ) are an important finding because the $5-\mathrm{HT}_{7}$ receptor density observed in various species (28) is less than a tenth of that of other serotonin receptors (37).

Although 5-HT 7 presents a low-sequence homology with other 5-HT receptors $(<40 \%$ according to Plassat et al. (38), Shen et al. (39), and Tsou et al. (40)), we chose to test the affinities of the 4 molecules toward $5-\mathrm{HT}_{1 \mathrm{~A}}$ and 5 $\mathrm{HT}_{6}$ receptors. This choice was justified by reports of difficulty for some $5-\mathrm{HT}_{7}$ ligands in discriminating between $5-\mathrm{HT}_{1 \mathrm{~A}}(21,41,42)$ and $5-\mathrm{HT}_{6}$ receptors $(43)$. We also showed that molecules of the FPMP series presented 5$\mathrm{HT}_{1 \mathrm{~A}}$ agonistic affinity $\left(\mathrm{EC}_{50}>10^{-5}\right)$. The FP3 series was more specific, showing neither $5-\mathrm{HT}_{1 \mathrm{~A}}$ nor $5-\mathrm{HT}_{6}$ affinity.

In vitro autoradiography revealed distribution patterns of the 4 radiotracers in accordance with $5-\mathrm{HT}_{7}$ localization. Previous brain distribution studies revealed the presence of $5-\mathrm{HT}_{7}$ receptors in numerous brain areas (including the cerebellum), with elevation in the hippocampus, thalamus, hypothalamus, and cerebral cortex $(6,22)$. The possible 5$\mathrm{HT}_{1 \mathrm{~A}}$ contribution revealed by in vitro pharmacology for the FPMP series was confirmed by higher hippocampus uptake in this series on autoradiography.

The in vitro competition studies confirmed that the FP3 series specifically binds $5-\mathrm{HT}_{7}$ receptors, because addition of SB269970, the specific 5- $\mathrm{HT}_{7}$ antagonist, displaced radiotracer binding dose-dependently. The lack of competition between SB269970 and either radiotracer of the FPMP series encourages us to focus future in vivo studies on the FP3 series $\left({ }^{18} \mathrm{~F}-4 \mathrm{FP} 3\right.$ and $\left.{ }^{18} \mathrm{~F}-2 \mathrm{FP} 3\right)$.

${ }^{18} \mathrm{~F}-4 \mathrm{FP} 3$ and ${ }^{18} \mathrm{~F}-2 \mathrm{FP} 3$ uptake and distribution in rat brain after ex vivo small-animal PET showed high uptake and displaceable binding after blockade by the corresponding cold molecules. Further, the $5-\mathrm{HT}_{7}$ selectivity of in vivo brain ${ }^{18} \mathrm{~F}-2 \mathrm{FP} 3$ binding was confirmed in the blocking study, in which ${ }^{18} \mathrm{~F}-2 \mathrm{FP} 3$ binding was decreased by a SB269970 bolus, whereas ${ }^{18} \mathrm{~F}-4 \mathrm{FP} 3$ binding was unchanged. This result confirmed that ${ }^{18} \mathrm{~F}-2 \mathrm{FP} 3$ presents the best radiopharmacologic properties of our 4 radiotracer candidates.

Final tests, to check the absence of radioactive metabolites in the brain, showed that more than $95 \%$ of brain radioactivity was due to unchanged ${ }^{18} \mathrm{~F}-2 \mathrm{FP} 3$, excluding any significant contribution of radiolabeled metabolites to specific binding in the brain. Taken together, the results indicate that ${ }^{18} \mathrm{~F}-2 \mathrm{FP} 3$ is a promising PET tracer for visualization and quantification of brain $5-\mathrm{HT}_{7}$ receptors.

Although these first studies were preclinical, we are confident that the radiopharmacologic profile of $2 \mathrm{FP} 3$ will be appropriate for clinical studies, because the $5-\mathrm{HT}_{7}$ receptor exhibits a high degree of interspecies homology, 
from rodents to humans $(\sim 95 \%$ (6)). However, a quantification approach with kinetic models is needed to complete this work and prepare its translation to human studies. In this aim, arterial input measures are currently in progress. Optimally, better affinity for $5-\mathrm{HT}_{7}$ receptors is to be preferred, because it is known that the specific binding of a radiotracer is a function of its affinity for the receptor relative to the density of the binding site. Consequently, the development of 2FP3 analogs is also being pursued, with chemical structures modified to optimize PET tracer properties, particularly in terms of affinity, which should be subnanomolar.

\section{CONCLUSION}

To our knowledge, this is the first report of a successful fluorinated PET radioligand for in vivo imaging of the serotonin $5-\mathrm{HT}_{7}$ receptor. The 4 PET radiotracers we synthesized had characteristics suitable for in vitro $5-\mathrm{HT}_{7}$ receptor probing; ${ }^{18} \mathrm{~F}-2 \mathrm{FP} 3$ notably showed specific and reversible in vivo binding to $5-\mathrm{HT}_{7}$ receptors. Further evaluation of this radioligand is warranted to investigate its potential as a $5-\mathrm{HT}_{7}$ radiotracer for human brain imaging.

\section{DISCLOSURE STATEMENT}

The costs of publication of this article were defrayed in part by the payment of page charges. Therefore, and solely to indicate this fact, this article is hereby marked "advertisement" in accordance with 18 USC section 1734.

\section{ACKNOWLEDGMENTS}

We thank Marion Alvarez for her help with radiochemistry and Sylvain Fieux for his help with animal procedures. The work was funded in part by the French National Research Agency ANR and a joint grant with the French Ministry of Research and Advanced Accelerator Applications (Saint Genis-Pouilly, France). No other potential conflict of interest relevant to this article was reported.

\section{REFERENCES}

1. Hoyer D, Clarke DE, Fozard JR, et al. International Union of Pharmacology classification of receptors for 5-hydroxytryptamine (serotonin). Pharmacol Rev. 1994;46:157-203.

2. Bard JA, Zgombick J, Adham N, Vaysse P, Branchek TA, Weinshank RL. Cloning of a novel human serotonin receptor (5-HT7) positively linked to adenylate cyclase. J Biol Chem. 1993;268:23422-23426.

3. Eglen RM, Jasper JR, Cahng DJ, Martin GR. The 5-HT7 receptor: orphan found. Trends Pharmacol Sci. 1997;18:104-107.

4. García-Alcocer G, Segura LC, García Peña M, Martínez-Torres A, Miledi R. Ontogenetic distribution of 5-HT2C, 5-HT5A, and 5-HT7 receptors in the rat hippocampus. Gene Expr. 2006;13:53-57.

5. Varnäs K, Thomas DR, Tupala E, Tiihonen J, Hall H. Distribution of 5-HT7 receptors in the human brain: a preliminary autoradiographic study using $\left[{ }^{3} \mathrm{H}\right]$ SB-269970. Neurosci Lett. 2004;367:313-316.

6. Martín-Cora FJ, Pazos A. Autoradiographic distribution of 5-HT7 receptors in the human brain using $\left[{ }^{3} \mathrm{H}\right]$ mesulergine: comparison to other mammalian species. Br J Pharmacol. 2004;141:92-104.

7. Leopoldo M. Serotonin ${ }_{7}$ receptors $\left(5-\mathrm{HT}_{7} \mathrm{Rs}\right)$ and their ligands. Curr Med Chem. 2004;11:629-661.
8. Pittalà V, Salerno L, Modica M, Siracusa MA, Romeo G. 5-HT7 receptor ligands: recent developments and potential therapeutic applications. Mini Rev Med Chem. 2007;7:945-960.

9. Thomas DR, Hagan JJ. 5-HT7 receptors. Curr Drug Targets CNS Neurol Disord. 2004;3:81-90.

10. Bonaventure P, Nepomuceno D, Hein L, Sutcliffe JG, Lovenberg T, Hedlund PB. Radioligand binding analysis of knockout mice reveals 5-hydroxytryptamine receptor distribution and uncovers 8-hydroxy-2-(di-n-propylamino)tetralin interaction with alpha $_{2}$ adrenergic receptors. Neuroscience. 2004;124:901-911.

11. Hedlund PB, Sutcliffe JG. Functional, molecular and pharmacological advances in 5-HT7 receptor research. Trends Pharmacol Sci. 2004;25:481-486.

12. Monti JM, Jantos H. Effects of the 5-HT 7 receptor antagonist SB-269970 microinjected into the dorsal raphe nucleus on REM sleep in the rat. Behav Brain Res. 2006; 167:245-250.

13. Mullins UL, Gianutsos G, Eison AS. Effects of antidepressants on 5-HT7 receptor regulation in the rat hypothalamus. Neuropsychopharmacology. 1999;21:352-367.

14. Mnie-Filali O, Lambas-Señas L, Scarna H, Haddjeri N. Therapeutic potential of 5-HT7 receptors in mood disorders. Curr Drug Targets. 2009;10:1109-1117.

15. Mnie-Filali O, Lambás-Señas L, Zimmer L, Haddjeri N. 5-HT7 receptor antagonists as a new class of antidepressants. Drug News Perspect. 2007;20:613-618.

16. Manuel-Apolinar L, Meneses A. 8-OH-DPAT facilitated memory consolidation and increased hippocampal and cortical cAMP production. Behav Brain Res. 2004;148:179-184.

17. Hedlund PB. The 5-HT7 receptor and disorders of the nervous system: an overview. Psychopharmacology (Berl). 2009;206:345-354.

18. Wang X, Yannan F, Jianbo L, Zhao Y, Jiayin M, Ning L. Selective inhibition of 5-HT7 receptor reduces CGRP release in an experimental model for migraine. Headache. 2010;50:579-587.

19. Yanarates O, Dogrul A, Yildirim V, et al. Spinal 5-HT7 receptors play an important role in the antinociceptive and antihyperalgesic effects of tramadol and its metabolite, O-desmethyltramadol, via activation of descending serotonergic pathways. Anesthesiology. 2010;112:696-710.

20. Lee CM, Farde L. Using positron emission tomography to facilitate CNS drug development. Trends Pharmacol Sci. 2006;27:310-316.

21. Leopoldo M, Berardi F, Colabufo NA, et al. Structure-affinity relationship study on N-(1,2,3,4-tetrahydronaphthalen-1-yl)-4-aryl-1-piperazinealkylamides, a new class of 5-hydroxytryptamine7 receptor agents. J Med Chem. 2004;47:6616-6624.

22. Kitson SL. 5-hydroxytryptamine (5-HT) receptor ligands. Curr Pharm Des. 2007;13:2621-2637.

23. Kikuchi C, Nagaso H, Hiranuma T, Koyama M. Tetrahydrobenzindoles: selective antagonists of the 5-HT7 receptor. J Med Chem. 1999;42:533-535.

24. Kikuchi C, Ando T, Watanabe T, et al. 2a-[4-(tetrahydropyridoindol-2-yl)butyl] tetrahydrobenzindole derivatives: new selective antagonists of the 5-hydroxytryptamine7 receptor. J Med Chem. 2002;45:2197-2206.

25. Andriès J, Lemoine L, Mouchel-Blaisot A, et al. Looking for a 5-HT7 radiotracer for positron emission tomography. Bioorg Med Chem Lett. 2010;20:3730-3733.

26. Zhang MR, Haradahira T, Maeda J, et al. Synthesis and preliminary PET study of the 5-HT7 receptor antagonist $\left[{ }^{11} \mathrm{C}\right] \mathrm{DR} 4446 . J$ Labelled Comp Radiopharm. 2002;45:857-866.

27. Lovell PJ, Bromidge SM, Dabbs S, et al. A novel, potent, and selective 5-HT(7) antagonist: (R)-3-(2-(2-(4-methylpiperidin-1-yl)ethyl)pyrrolidine-1-sulfonyl) phen ol (SB-269970). J Med Chem. 2000;43:342-345.

28. Thomas DR, Atkinson PJ, Hastie PG, Roberts JC, Middlemiss DN, Price GW. $\left[{ }^{3} \mathrm{H}\right]-\mathrm{SB}-269970$ radiolabels 5-HT7 receptors in rodent, pig and primate brain tissues. Neuropharmacology. 2002;42:74-81.

29. Andries J, Lemoine L, Le Bars D, Zimmer L, Billard T. Synthesis and radiolabelling of potent 5-HT7 receptor PET radiotracers. Eur J Med Chem. In press.

30. Cerep Services. Available at: http://www.cerep.fr/Cerep/Users/index.asp. Accessed September 28, 2011.

31. Sempere-Roldan P, Chereul E, Dietzel O, et al. Raytest ClearPet, a new generation small animal PET scanner. Nucl Instrum Methods Phys Res A. 2007;571:498-501.

32. Snyder RS, Niemer WT. A Stereotaxic Atlas of the Cat Brain. Chicago, IL: University of Chicago Press; 1961.

33. Jasper HH, Ajmone-Marsan C. A Stereotaxic Atlas of the Diencephalon of the Cat. Ottawa, Canada: The National Research Council of Canada editors; 1954.

34. Bojarski AJ. Pharmacophore models for metabotropic 5-HT receptor ligands. Curr Top Med Chem. 2006;6:2005-2026.

35. Thomas DR, Atkinson PJ, Ho M, et al. [(3)H]-SB-269970: a selective antagonist radioligand for 5-HT(7) receptors. Br J Pharmacol. 2000;130:409-417.

36. Waterhouse RN. Determination of lipophilicity and its use as a predictor of blood-brain barrier penetration of molecular imaging agents. Mol Imaging Biol. 2003;5:376-389.

37. Paterson LM, Tyacke RJ, Nutt DJ, Knudsen GM. Measuring endogenous 5-HT release by emission tomography: promises and pitfalls. J Cereb Blood Flow Metab. 2010;30:1682-1706. 
38. Plassat JL, Amlaiky N, Hen R. Molecular cloning of a mammalian serotonin receptor that activates adenylate cyclase. Mol Pharmacol. 1993;44:229236.

39. Shen Y, Monsma FJ Jr, Metcalf MA, Jose PA, Hamblin MW, Sibley DR. Molecular cloning and expression of a 5-hydroxytryptamine7 serotonin receptor subtype. J Biol Chem. 1993;268:18200-18204.

40. Tsou AP, Kosaka A, Bach C, et al. Cloning and expression of a 5-hydroxytryptamine7 receptor positively coupled to adenylyl cyclase. J Neurochem. 1994;63:456-464.
41. Medina RA, Sallander J, Benhamú B, et al. Synthesis of new serotonin 5-HT7 receptor ligands. Determinants of 5-HT7/5-HT1A receptor selectivity. J Med Chem. 2009;52:2384-2392.

42. Badarau E, Suzenet F, Bojarski AJ, Fînaru AL, Guillaumet G. Benzimidazolonebased serotonin 5-HT1A or 5-HT7R ligands: synthesis and biological evaluation. Bioorg Med Chem Lett. 2009;19:1600-1603.

43. Volk B, Barkóczy J, Hegedus E, et al. (Phenylpiperazinyl-butyl)oxindoles as selective 5-HT7 receptor antagonists. J Med Chem. 2008;51:2522-2532.

\section{Erratum}

In 3 recent articles, the affiliation list for one of the authors, Dr. Ilan Ziv, was incomplete. The articles are "Molecular Imaging of Neurovascular Cell Death in Experimental Cerebral Stroke by PET" (J Nucl Med. 2008;49:1520-1528); "Small-Molecule Biomarkers for Clinical PET Imaging of Apoptosis" ( $\mathrm{N} \mathrm{Nucl} \mathrm{Med.} \mathrm{2010;51:837-840);} \mathrm{and} \mathrm{"18} \mathrm{F-}$ ML-10, a PET Tracer for Apoptosis: First Human Study" (J Nucl Med. 2011;52:720-725). For all 3 articles, the full affiliation list of Dr. Ziv is as follows: Aposense Ltd., Petach-Tiqva; The Sackler School of Medicine, Tel-Aviv University, Tel-Aviv; and the Department of Neurology, Rabin Medical Center, Petach-Tiqva, Israel. The authors regret the error. 